\title{
DAMPAK CYBER BULLYING PADA PRIBADI SISWA DAN PENANGANANNYA DI ERA PANDEMI COVID-19
}

\author{
Endah Ruliyatin, S.Psi \\ SMK Negeri 8 Jember \\ email : endah.ruliyatin10@gmail.com \\ Dwi Ridhowati, S.Pd \\ SMP Negeri 2 Merakurak Tuban \\ Email : dwiridhowati@gmail.com
}

\begin{abstract}
Abstrak
Semakin pesat perkembangan teknologi digital saat ini, secara tidak langsung berdampak lajaran pada perkembangan komunikasi dan gaya hidup masyarakat. Seperti halnya penggunaan internet dalam masa pandemi covid-19 saat ini dalam kehidupan sehari-hari masyarakat tidak bisa terlepas dari gawai, khususnya pada anak-anak dan siswa usia pelajar mereka pembelajarannya melalui daring, otomatis komunikasi antar teman, guru semuanya di lakukan dengan chat online. Penggunaan internet pada siswa yang di luar kendali pengawasan orang tua, bisa saja menyebabkan salah satu ancaman pada peekembangan komunikasi siswa itu sendiri, yang sering terjadi ancaman komunikasi berbentuk Cyber Bullying.

Cyber Bullying merupakan bagian dari problematika siswa, terkadang pelaku tidak menyadari dan bertindak di luar batas norma kepada orang lain dengan cara mengirim statement atau memosting gambar/foto yang menjatuhkan kredibilitas harga diri orang lain, melakukan ancaman, menghina, serta melakukan serangan sosial media dalam berbagai bentuk, dengan memanfaatkan jaringan internet atau teknologi digital lainnya sebagai medianya. Selama pembelajaran daring, orang tua/anggota keluarga wajib memantau putra-putrinya dalam menggunakan media sosial untuk meminimalisir tindakan Cyber Bullying. Metode penelitian menggunakan studi literatur dengan cara menganalisis beberapa artikel yang digunakan untuk menjawab pertanyaan penelitian. Hasil penelitian menunjukkan identifikasi perilaku yang dialami oleh pelaku dan korban cyber bulliying.
\end{abstract}

Kata Kunci: Cyber Bullying, Pribadi Siswa.

\begin{abstract}
The more rapid the development of digital technology today, indirectly it has an impact on the development of communication and people's lifestyles. As with the use of the internet during the current Covid-19 pandemic in people's daily lives, it cannot be separated from devices, especially for children and students of student age, their learning is online, automatic communication between friends, teachers are all done by online chat . The use of the internet on students that is outside the control of parental supervision, could cause a threat to the development of student communication itself, which often occurs communication threats in the form of cyber bullying.

Cyber Bullying is part of student problems, sometimes perpetrators do not realize and act outside the norm limits to others by sending statements or posting pictures / photos that drop the credibility of other people's self-esteem, make threats, insult, and carry out social media attacks in various ways. form, by utilizing the internet network or other digital technology as the medium. During online learning, parents / family members are required to monitor their children using social media to minimize cyber bullying. The research method uses a literature study by analyzing several articles used to answer research questions. The results showed the identification of behavior experienced by perpetrators and victims of cyber bullying.
\end{abstract}

Keywords: Cyber Bullying, Student Personal.

\section{PENDAHULUAN}

Masa Pandemi Covid-19 saat ini ada beberapa hal yang berperan penting pada remaja yaitu teman sebaya dan social media. Teman sebaya (peer group) memiliki peran penting dan berpengaruh dalam kehidupan siswa karena mereka dalam rentang usia remaja dimana relasi signifikannya adalah teman sebaya. Selain itu keberadaan gawai apalagi ditunjang beragam aplikasi social media yang menawarkan beberapa konten-konten menarik untuk menarik perhatian siswa. Seperti halnya tiktok, whatsapp, twitter dll. Meningkatnya penggunaan teknologi informasi 
dan perangkat komunikasi modern di kalangan anak ditenggarai menimbulkan kerentanan baru yang dapat menyebabkan anak terlibat dalam cyberbullyingbaik sebagai pelaku maupun korban (Fanti dkk., 2008).

Berbagai penelitianlintas negara menunjukkan bahwa cyberbullying merupakan masalah yang mengkhawatirkanbaik di negara-negara maju maupun wilayah berkembang. Hinduja dan Patchin, 2006)dalam studinya terhadap 1378 remaja di Amerika Serikat menemukan bahwa prevalensi pengalaman bullying berada pada kisaran 17 persen (sebagai pelaku) dan 34 persen sebagai korban. Sebuah studi multi-nasional oleh Atanashiou dkk. (2008) dikalangan remaja di7 negara Eropa: Romania, Jerman, Yunani, Polandia, Belanda,Iceland, dan Spanyol menemukanpengalaman bullying berkisar pada angka 13 hingga 37\%). Proporsiremaja yang melaporkan pernah menjadi cyberbullying dalam 12 bulan terakhir sebanyak $37 \%$ di Romania(tertinggi), $27 \%$ di Jerman, dan $13 \%$ di Belanda(terendah). Sebuah hasil pooling yang dilakukan oleh UNICEF terhadap lebih dari 170 ribu remaja dan dewasa muda berusia 13 s sampai dengan 24 tahun di 27 negara di Asia, Afrika, Eropa,Amrika Latin, dan Mediterania (sebagian besar wilayah negara berkembang) termasuk Indonesia menunjukkan bahwa 1 dari 3 responden pernah mengalami bullying online. Fakta ini mematahkan anggapan bahwa bullying hanya merupakan isu sentral baginegara-negara maju. (UNICEF, 2019).

Siswa yang berada di usia remaja yang masih dalam masa pencarian jati diri, labil dalam berpikir dan krisis identitas dikatakan sangat bergantung pada pengaruh teman-teman sebaya dalam bertindak dan berpikir, lingkungan teman sebaya merupakan hal yang besar pengaruhnya yang dapat berdampak positif maupun negatif, salah satunya Cyber Bullying. Pengaruh negatif ini biasa dimunculkan melalui tekanan-tekanan dalam pergaulan. Ada beberapa tekanan dalam pertemanan siswa saat ini antara lain: rasa iri hati (iri dengan gawai milik teman), intoleransi, dan persaingan antar gank. Perilaku ini sering kita jumpai dalam berita-bertita tentang kenakalan siswa di televisi, sebab dari perilaku siswa yang menyimpang dan berakhir dengan permasalahan dan permusuhan biasanya ditunjukkan oleh siswa yang memiliki kontrol moral dan keterampilan kepemimpinan yang rendah serta dukungan lingkungan yang kurang baik.

Dalam masa pandemi covid-19 ini keterbukaan informasi sangatlah luas,sangat mudah untuk mengakses apapun yang kita inginkan melalui gawai. Tiap detik bisa update status, saling berbalas chat di group whatsapp, tampilan demonstrasi dengan anarkis, serta bentrok warga dan aparat merupakan gambaran perilaku kekerasan yang sangat mudah kita lihat melalui media sosial. Hal tersebut merupakan tontonan kekerasan yang sering dilihat oleh siswa dan dapat berdampak pada pola pikir siswa untuk melakukan Cyber Bullying terhadap sesama teman.

Cyber Bullying merupakan fenomena yang tidak asing lagi bagi kita dan sering terjadi di kalangan siswa. Kasus Cyber Bullying biasanya terjadi pada pelajar. Pelaku Cyber Bullying akan mengancam, melakukan penghinaan kapada kawannya sehingga kawannya tersebut tersulut emosi atau lebih parah lagi, korban Cyber Bullying akan mengalami penyimpangan perilaku, mengisolasi diri, tidak mau ke sekolah hingga depresi dan timbul ingin mengakhiri hidupnya.

Siswa yang biasa menjadi pemicu tekanan dalam lingkungan teman sebaya rawan melakukan Cyber Bullying terhadap anak lain yang dianggapnya lemah dan tidak berdaya (Santrock, 2012). Sementara itu, sebuah penelitian yang dilakukan Hinduja \& Patchin menyebutkan bahwa dari dua ribu siswa di sekolah menengah di Amerika, sebanyak 20\% melaporkan pernah berpikir untuk mengakhiri hidupnya dan 19\% lainnya telah berniat untuk bunuh diri akibat mengalami pembully-an baik secara tatap muka maupun secara online (Cyber Bullying), jenis pem-bully-an biasanya berupa sindiran kasar dan viktimasi (berupa fitnah dan tuduhan yang memojokkan) (Hinduja \& Patchin, 2010).

Di masa Pandemi Covid-19 intensitas siswa menggunakan media sosial meningkat tajam dibanding sebelum pandemi covid-19. Hal ini membuat siswa cenderung mengikuti tren yang viral dalam media sosial, seperti halnya aktif di media Tiktok, jika teman sejawatnya tidak bisa mengikuti perkembangan info yang lagi viral otomatis akan menjadi bahan ejekan sesama teman sejawatnya, konflik interpersonal antar siswa sering terjadi melalui sosial media bahkan yang sering terjadi foto teman dijadikan bahan ejekan di status Whatsapp, twitter dsb.

Saat ini beberapa bentuk,., konflik dan agresi antar siswa dilakukan secara media sosial online, hal ini dikarenakan di 'dunia' online, siswa merasa lebih bebas berekspresi dan tidak dibatasi oleh aturan orang dewasa (Ontario Centre of Excellence for Child and Youth Mental Health, 2015).

Bentuk konflik yang biasa dilakukan secara online bisa disebut dengan Cyber Bullying. Ada perbedaan signifikan antara Bullying biasa dengan Cyber Bullying, Cyber Bullying dilakukan secara anonimus dan kapan saja, dimana saja (Notar, Padgett, \& Roden, 2013). Cyber Bullying pada siswa sering dilakukan melalui sosial media seperti Whatsapp, Tiktok, Facebook, Twitter, dan Instagram (Ontario Centre of Excellence for Child and Youth Mental Health, 2015). Orang tua atau peran keluarga yang seharusnya mengawasi kehidupan putraputrinya kebanyakan justru tidak dapat melakukan 
perannya dengan baik karena kurang memiliki keahlian dalam menggunakan teknologi, yang lebih sering lagi Handphone siswa/putra-putrinya di beri kode atau password jadi tidak semua orang bisa menggunakan handphone tersebut, padahal Cyber Bullying terbukti memiliki dampak negatif yang lebih besar pada perkembangan siswa dibandingkan bullying tradisional dan berefek pada masalah sosial dan psikologis jangka panjang pada korban yang dibully (Notar, Padgett, \& Roden, 2013).

Dalam sebuah penelitian menyebutkan bahwa siswa korban Cyber Bullying hampir dua kali lebih banyak memiliki niat mengakhiri hidupnya dibandingkan siswa yang tidak menerima Cyber Bullying, fenomena bunuh diri akibat menerima agresi secara online ini juga disebut dengan cyberbullicide (Hinduja \& Patchin, 2010). Dalam penelitiannya pula Hinduja dan Patchin (2010) menyebutkan bahwa siswa baik yang mendapatkan Cyber Bullying maupun traditional bully lebih banyak berpikir untuk bunuh diri apabila mendapat bentuk bullyan berupa viktimasi (victimization), seperti dirumorkan akan hal-hal yang negatif, daripada mereka yang dibully dengan cara disindir dengan kasar. Penelitian tersebut diperkuat dengan penelitian lain yang menyebutkan, bahwa peer victimization melalui Cyber Bullying berkaitan dengan meningkatnya pikiran untuk mengakhiri hidup pada siswa itu sendiri dibandingkan dengan Bullying biasa.

Cyber Bullying merupakan problematika anak dan siswa yang harus dihadapi dan dicari solusinya karena Cyber Bullying mengakibatkan korbannya berpikir negatif, salahsatunya bertindak diluar kewajaran, membunuh atau bunuh diri disamping itu, Cyber Bullying juga menyebabkan seorang anak bersikap apatis dengan lingkungan sekitar.

\section{METODE}

Jenis penelitian ini adalah penelitan kepustakaan (library research), yaitu serangkaian penelitian yang berkenaan dengan metode pengumpulan data pustaka, atau penelitian yang obyek penelitiannya digali melalui beragam informasi kepustakaan. Data yang digunakan dalam penelitian ini adalah data sekunder. Metode pengumpulan data yang digunakan dalam penelitian ini adalah metode dokumentasi. Metode dokumentasi merupakan metode pengumpulan data dengan mencari atau menggali data dari literatur yang terkait dengan apa yang dimaksudkan dalam rumusan masalah. Analisis data yang digunakan dalam penelitian ini adalah analisis anotasi bibliografi (annotated bibliography). Anotasi berarti suatu kesimpulan sederhana dari suatu artikel, buku, jurnal, atau beberapa sumber tulisan yang lain, sedangkan bibliografi diartikan sebagai suatu daftar sumber dari suatu topik.

\section{HASIL DAN PEMBAHASAN}

\section{Pengertian Cyber Bullying}

Cyber Bullying jika diterjemahkan ke dalam bahasa Indonesia berarti perundungan siber dengan maksud intimidasi, mengancam dan pelecehan yang dilangsungkan baik secara verbal maupun fisik. CyberBullying bisa juga diartikan sebagai pelecehan, intimidasi, ancaman dan penghinaan yang dilakukan pelaku (bully) kepada korban dunia maya (internet) melalui media sosial. Cyber Bullying merupakan perlakuan tidak menyenangkan atau perlakuan yang menjatuhkan martabat seseorang yang dilakukan oleh individu atau sekelompok orang, melalui bantuan alat elektronik/media sosial yang dilakukan berulang dan terus menerus pada seorang target yang kesulitan membela diri (Smith dkk, 2008).

Medianya bisa berupa chatting Whatsapp, Instagram, line, instagram, Tiktok, status facebook, twitter, chat room dan sebagianya, baik yang melalui komputer ataupun ponsel. Di sebut Cyber Bullying ketika pelaku menyerang secara terus menerus dan terang-terangan kepada si korban. Misalnya pelaku dengan sengaja dan sadar memosting di status Whatsapp, facebook atau media sosial lainnya kepada lawannya untuk menjatuhkan harga diri atau mengintimidasi. Selain itu Cyber Bullying dapat juga melalui media sosial lainnya seperti halnya blog, atau halaman web untuk merusak reputasi, mempermalukan dan mengintimidasi lawannya. Bentuknya bermacammacam, misalnya menyebarkan berita hoax, memposting foto-foto memalukan orang lain, pelecehan seksual (pornografi), ancaman hingga tindakan yang berujung pemerasan.

Secara tidak langsung Cyber Bullying sering kita tonton di acara live televisi. Hal itu yang disebut bulliest. bulliest ini sering kita dapati di forum-forum bebas dan di jejaring sosial seperti youtube dan facebook. Media youtube dan group facebook juga menjadi tempat umpatan bagi pelaku Cyber Bullying. Awalnya memang berdiskusi dengan baik tapi pada akhirnya terdapat selisih pendapat dan berujung dengan bulliest. Cyber Bullying merupakan bentuk intimidasi, penghinaan, ancaman kekerasan yang sering dialami siswa dan dilakukan teman sebayanya melalui media sosial internet.

\section{Dampak Cyber Bullying}

Ketika siswa mengalami Cyber Bullying, korban merasakan emosi negatif (tertekan, takut, malu, sedih, marah, dendam, kesal, tidak nyaman, terancam) namun tidak berdaya menghadapinya tidak bisa menghadapi dengan sendirinya. Dalam jangka panjang dan berulangulang emosi-emosi tersebut dapat berujung pada munculnya suasana hati rendah diri dan putus asa. Kesulitan beradaptasi dengan lingkungan sosial juga muncul pada pribadi korban, mengisolasi diri, Paling 
ekstrim dari dampak psikologis ini adalah kemungkinan untuk timbulnya gangguan psikologis pada korban Cyber Bullying, seperti rasa cemas yang berlebihan, ingin mengakhiri hidupnya, memiliki rasa takut berlebihan, depresi dan gejala-gejala gangguan stres pasca-trauma (post-traumatic stress disorder).

Aksi Cyber Bullying di media social dapat berdampak yang cukup serius, terutama kepada anak yang menjadi korban aksi Cyber Bullying. Dampak Cyber Bullying, yaitu; (a) Rendahnya kepercayaan diri / minder, (b) Depresi, (c) Pemalu, (d) Prestasi akademik merosot, (e) Merasa terisolasi dalam pergaulan, (f) Ingin mencoba mengakhiri hidup.

Anak yang menjadi korban Cyber Bullying dapat dideteksi melalui beberapa ciri, sebagai berikut; (a) Enggan berbicara, (b) Sering sakit /mengeluh sakit secara tiba-tiba, (c) emosi tidak stabil, (d) Sulit tidur atau sering mengigau, (f) Sering marah-marah, rasa amarah dan benci semakin mudah meluap dan meningkat, (g) Kesulitan mencari teman atau berteman dengan kawan baru

Mengingat pembelajaran pada masa pandemi covid-19 ini anak/siswa cenderung bayak dirumah maka tanggung jawab terbesar pada orang tua dan anggota keluarga. Oleh karena itu, orang tua hendaknya selalu memperhatikan anak-anaknya yang sedang menglamai pembelajaran jarak jauh sistem daring. Apabila orang tua menemukan satu atau beberapa ciri-ciri seperti disebutkan di atas, hendaknya segera melakukan pendekatan kepada anak untuk mencegah lebih jauh terjadinya Cyber Bullying. Tindakan yang perlu dilakukan orang tua/keluarga jika anak menjadi korban Cyber Bullying diantaranya; (a) Komunikasi (berbicara) dengan orangtua anak yang melakukan bully terhadap anak, (b) Mengkomunikasikan masalah Cyber Bullying kepada sekolah hal ini bisa di wakili oleh guru bimbingan konseling/konselor, wali kelas dsb. (c) menjalin komunikasi dengan baik dan instens kepada anak, agar anak lebih tenang di beri penguat, motivasi dan advokasi

Dampak dari Cyber Bullying tidak selalu dirasakan oleh target (seseorang yang di-bully), tetapi juga orang lain yang melihat aksi Cyber Bullying tersebut. Anak (siswa) yang menjadi korban Cyber Bullying (target) biasanya mengalami gangguan kondisi mental, kesehatan fisik, tidak semangat belajar dan pergaulan sosialnya namun juga muncul rasa melawan atau keinginan membully balik kepada pembully sebagai bentuk balas dendam dan bisa berujung pada perkelahian, hingga pembunuhan.

\section{Pencegahan Cyber Bullying}

Tindakan representative untuk mencegah terjadinya $C y b e r$ Bullying pada saat masa pandemi covid-19, antara lain:

a. Orang tua/anggota keluarga berperan aktif memantau komunikasi dan jejaring pertemanan putra/putrinya, hal ini efektif untuk mengurangi gesekan antar teman serta dapat mengenal karakter teman-teman putraputrinya.

b. Menjalin komunikasi dengan teman-teman si anak agar lebih mudah mengenali karakter temannya serta mengenali latar belakang keluarganya, sehingga meminimalisir anak terseret ke pergaulan yang tidak di inginkan.

c. Menghindari asumsi dan penghakiman massa secara langsung di media-media sosial, walaupun hanya dengan meretweet/repost, karena efek retweet/repost ini berdampak pada amplifikasi statement yg bisa saja saling serang asumsi atau debat kusir yang tanpa ada solusi.

\section{PENUTUP}

\section{Simpulan}

Perilaku Cyber Bullying yang berlangsung secara berkepanjangan mampu berdampak dalam mematikan rasa percaya diri seorang anak, hal itu mampu menjadikan anak tersebut menjadi murung, khawatir, dan selalu merasa bersalah karena merasa tidak mampu mengatasi gangguan yang menimpanya. Bahkan dalam situasi lain, seorang korban Cyber Bullying biasanya tidak bisa berpikir jernih selalu berpikir untuk bunuh diri, karena merasa tidak tahan lagi dengan gangguan atau ancaman oleh pembully.

Korban Cyber Bullying akan mengalami rasa tertekan, stress yang memicu perilaku untuk melakukan tindakantindakan yang diluar kewajaran dan membahayakan diri maupun orang lain, seperti berkelahi, lari dari rumah, serta menggunakan minum-minuman keras atau narkoba. Untuk mencegah terjadinya Cyber Bullying tersebut, dapat dilakukan melalui beberapa cara.

\section{Saran}

Berikut beberapa cara yang dapat dilakukan untuk mencegah Cyber Bullying khususnya pada saat masa pandemic covid-19 saat ini;

a. Orang tua/anggota keluarga berperan aktif memantau komunikasi dan jejaring pertemanan putra/putrinya, hal ini efektif untuk mengurangi gesekan antar teman serta dapat mengenal karakter teman-teman putra-putrinya.

b. Menjalin komunikasi dengan teman-teman si anak agar lebih mudah mengenali karakter temannya serta mengenali latar belakang keluarganya, sehingga meminimalisir anak terseret ke pergaulan yang tidak di inginkan.

c. Menghindari asumsi dan penghakiman massa secara langsung di media-media sosial, walaupun hanya dengan meretweet/repost, karena efek retweet/repost ini berdampak pada amplifikasi 
statement yg bisa saja saling serang asumsi atau debat kusir yang tanpa ada solusi

d. Guru bimbingan dan konseling/Konselor setidaknya dalam pembelajaran daring memantau siswanya melalui akun group Whatsapp/maupun media social lainnya.

e. Mengoptimalkan peran sahabat atau konseling teman sebaya.

\section{DAFTAR PUSTAKA}

Ali Mohamad dan Asrori Mohamad, (2006). Psikologi Remaja Perkembangan Peserta Didik. Jakarta : Bumi Aksara.

Astuti, P.R. (2008). Meredam Bullying: 3 cara efektif mengatasi kekerasan pada anak. Jakarta: PT. Grasindo.

Hinduja, S., \& Patchin, J. (2010). Cyber Bullying Research Summary : Cyber Bullying and Suicide. Cyber Bullying Research Center .

Notar, C. E., Padgett, S., \& Roden, J. (2013). Cyber Bullying: Resources for Intervention and Prevention. Universal Journal of Educational Research, 133-145. di akses tanggal 07 Oktober 2020

Perdana, Anugrah, Putra Adi M, Shofaria, Nurida. (2017). Penanganan Cyber Bullying pada siswa SMK. Tersedia: https://fdokumen.com/document/ di akses tanggal 07 Oktober 2020

Satalina, D. (2014). Kecenderungan perilaku cyberbullying ditinjau dari tipe kepribadian ekstrovert dan introvert. Jurnal Ilmiah Psikologi Terapan, 2(2), 294-310. di akses tanggal 07 Oktober 2020

Fanti, K.A., Demetriou, A.G. \&Hawa, V.V. (2012). A longitudinal study of cyberbullying: Examining risk and protective factors. European Journal of Developmental Psychology, 9(2), 168-181.

Athanasiou, K., Melegkovits, E., Andrie, E.K. Magoulas, C., Tzavara, C.K., Richardson, C., Greydanus, D., Tsolia, M., \& Tsitsika, A.K. (2018). Crossnational aspects of cyberbullying victimization among 14-17-year-old adolescents across seven European countries. BMC Public Health, 18.
UNICEF. (5 Februari 2019). Safer Internet Day: UNICEF calls for concerted action to prevent bullying and harassment for the over 70 per cent of young people online worldwide. Diunduh pada 1 Juli 2020 melalui https://www.unicef.org/eca/pressreleases/safer-internet-day-unicef-callsconcerted-action-prevent-bullying-andharassment 